\title{
Using Eco-innovation Index to Measure the Eco-innovation Performance in the Global Knowledge Economy: Evidence from Slovakia
}

\author{
Lubica Lesáková ${ }^{1, *}$, Peter Laco $^{1}$ \\ ${ }^{1}$ Matej Bel University, Faculty of Economics, Tajovského 10, 97590 Banská Bystrica, Slovakia
}

\begin{abstract}
Eco-innovation and green technologies are the key to Europe's future and they are at the heart of the EU policies. To step towards the sustainable economic growth, there is a need for much more ecoinnovation. The aim of the paper is to use the eco-innovation index as an instrument to measure the eco-innovation performance of a country in the global knowledge economy, to analyse and assess the components and indicators of eco-innovation index for Slovakia in the year 2017 and to compare them with those of EU 28. Identified and discussed will be the areas in which the main strengths and weaknesses are evident, formulated will be the main implications for managers and policy makers in Slovakia to improve the state in mentioned area. Following the aim of the paper a set of research questions will be formulated. Our study is based on secondary sources of data coming from the Eurostat and Eco-Innovation Observatory. The methods used in the paper are the method of casual analysis, deduction, abstraction, comparison as well as the synthesis.
\end{abstract}

\section{Introduction}

Europe's economic growth over many decades has been fuelled by the intensive use of resources. However today it faces multiple challenges of stimulating the growth, while ensuring that this growth is economically and ecologically sustainable. Energy use, water scarcity, land shortages, the depletion of materials and the management of waste are among the most discussed issues posing sustainability challenges [1].

The EU's economic prosperity and well being is linked to its natural environment and the global demand for renewable energy and resource-efficient solutions will be a source of jobs and economic growth in the years to come. To secure (reaching) the environmental protection and economic growth, eco-innovations have a central role. Eco-innovation becomes an emerging priority of EU policy relating to different aspects of almost all industries [2].

A significant step forward for eco-innovation is the Eco-Innovation Action Plan (EcoAP) launched by the European Commission in December 2011. Eco-innovation Action Plan is an important element of the European policy framework for sustainable consumption and production. It aims to transfer Europe into a more competitive resource-

* Corresponding author: lubica.lesakova@umb.sk 
efficient economy and acknowledges the key role of eco-innovation in the context of job creation, growth and competitiveness, as well as environmental protection [3].

At the macro level it is necessary to understand environmental, economic and social dimensions in which eco-innovation strategies may develop. The new global economy is not only a knowledge economy, but also an economy based on responsible behaviour [4]. In the knowledge-based development, the key to growth and prosperity relies on the issues of acquiring, creating, developing, storing and applying knowledge for a sustainable economic, social and environmental development [5].

To step towards the sustainable economic growth, there is a need for much more ecoinnovations to appear in all sectors of EU [6].

\section{Theoretical background}

Eco-innovation is a concept that is difficult to define because of the complexity of the subject. Fussler and James [7] define eco-innovation as "new products and processes which provide customer and business value but significantly decrease environmental impacts". Hillebrand and Driessen [8] state that green innovation "does not have to be developed with the goal of reducing the environmental burden" but it "does however, yield significant environmental benefits". Arundel and Kemp [9] emphasize that eco-innovation "can be motivated by economic or environmental considerations".

Rennings [10] perceives eco-innovations as new approaches that help reduce environmental burdens or achieve ecological targets and differentiate between technological, organizational, social, and institutional ones.

Originally, the concept of eco-innovation focused on progress in the field of technology and processes, with an intention to reduce environmental impacts of economic activities. In time, eco-innovation's awareness has essentially broadened, particularly where the following aspects are concerned [11]:

- Eco-innovation does not only apply to clean and resource-efficient technologies that are specifically aimed at reducing environmental harm. Every product or service generating an environmental benefit (reduced use of natural resources and lower use of emissions and waste) in relation to relevant alternatives should be recognized as an eco-innovation [12].

- Eco-innovation encompasses all environmental improvements across the whole product life cycle, concerning the way they are designed, produced, used, reused, and recycled [13].

- Eco-innovation, in a broader perspective, also embraces environmentally oriented organizational and marketing approaches, including eco-innovative business models, which can have effects on the consumer behaviour [14].

Concentrating on most of these additional aspects, the expert group of the EcoInnovation Observatory defines eco-innovation as the following: Eco-innovation is the introduction of any new or significantly improved product (good or service), process, organizational change or marketing solution that reduces the use of natural resources (including materials, energy, water and land) and decreases the release of harmful substances across the whole life-cycle [13].

\section{Aim and methods of research}

To measure the eco-innovation performance in all EU member states the Eco-Innovation Observatory has developed a composite index, so called "Eco-innovation index" (EII). The Eco-innovation index demonstrates the eco-innovation performance of a country compared with the EU average and with the EU top performers. It is equated in scores and shows how 
well individual member states perform in different dimensions of eco-innovation compared to the EU average (EU EII is equated with 100, EU EII=100). Eco-innovation index is a composite index that is based on 16 indicators which are aggregated into five components: eco-innovation inputs, eco-innovation activities, eco-innovation outputs, resource efficiency outcomes and socio-economic outcomes.

Main aim of the paper is to use the eco-innovation index as an instrument to measure the eco-innovation performance of a country (Slovakia) in the global knowledge economy.

To fulfil the main aim of the paper we formulated 3 partial aims:

1. To assess the overall eco-innovation performance of Slovakia in the year 2017, to analyse and assess all the components and indicators of eco-innovation index for Slovakia and to compare them with those of EU 28 - average.

2. To identify main strengths and weaknesses of eco-innovation performance for Slovakia.

3. To formulate main implications for managers and policy makers in Slovakia to improve the state in mentioned area.

The study is qualitative and descriptive in nature and most of the date is based on secondary sources of data coming from Eurostat and Eco-Innovation Observatory. The methods used in the paper are the method of casual analysis, deduction, abstraction, comparison as well as the synthesis.

\section{Results and discussion}

The Eco-Innovation Observatory is publishing (starting the year 2010) the eco-innovation index for all EU member states. In the year 2017 all EU countries were clustered into three groups [15]:

1. Eco-innovation leaders, with score significantly higher than the EU average (a score of $>115)$

2. Average eco-innovation performers with scores around the EU average (a score between 85 and 115);

3. EU countries with performance around $85 \%$ or less compared to the EU average (with a score $<85$ ).

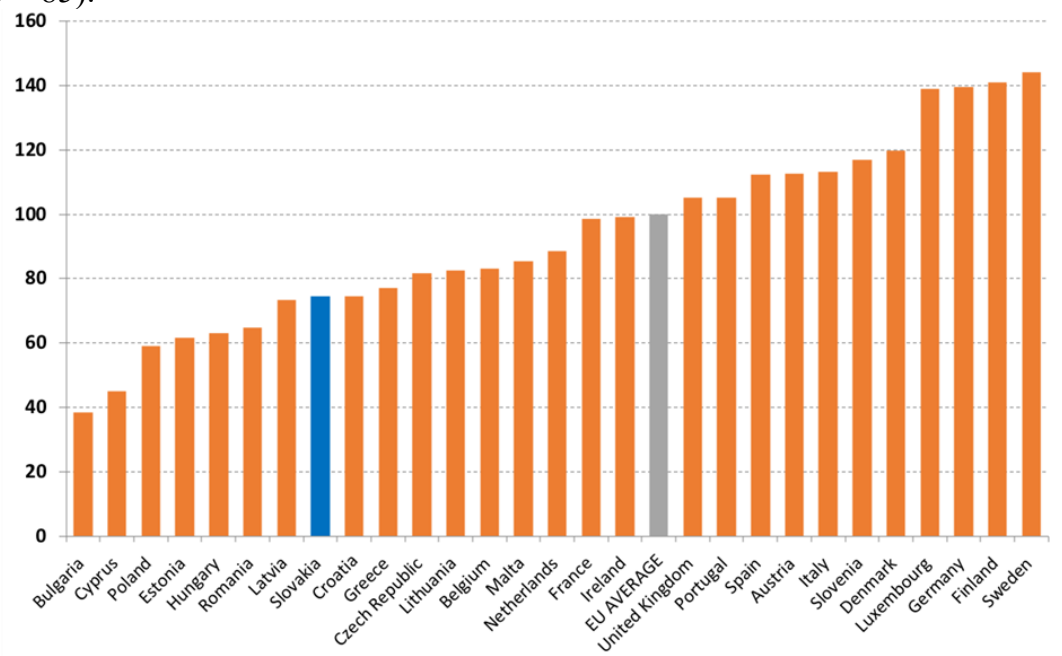

Fig. 1. EU 28 Eco-Innovation index 2017, composite index. 
According to the Eco-Innovation Index in the year 2017, Sweden leads the ranking of all EU countries, with an aggregated score of 144. Finland (141), Germany and Luxembourg (139 each) follow the Sweden. Nine EU member states obtained scores around the EU average of 100 and were therefore labelled as average eco-innovation performers. The aggregated eco-innovation scores in this group range from 113 (Italy and Austria) to 86 (Malta). Except of Belgium, all countries in the last group of countries in eco-innovation were member states that joined the EU in or after 2005. Aggregated scores in this group of countries range from 83 (Belgium) to 38 (Bulgaria).

Slovakia with an overall score of 75 in 2017 is on the 20th place among 28 EU member states. The score of 75 means that Slovakia's overall eco-innovation performance is $25 \%$ below the EU average. The country's performance has improved compared to 2010 when the overall score was only 43 (it was ranked on 23th place); in the year 2015 eco-innovation index has increased to 61, but with the score 75 in 2017 Slovakia still belongs to the last group of countries with low eco-innovation performance [16].

The eco-innovation index is an aggregated index giving a general overview of the overall eco-innovation performance across the EU and it does not allow to identify strong or weak areas. It offers the disaggregation of the composite index into five components (sub-indices). Figure 2 illustrates scores of the five sub-indices (components) in the ecoinnovation index: eco-innovation inputs, eco-innovation activities, eco-innovation outputs, resource-efficiency outcomes and socio-economic outcomes.

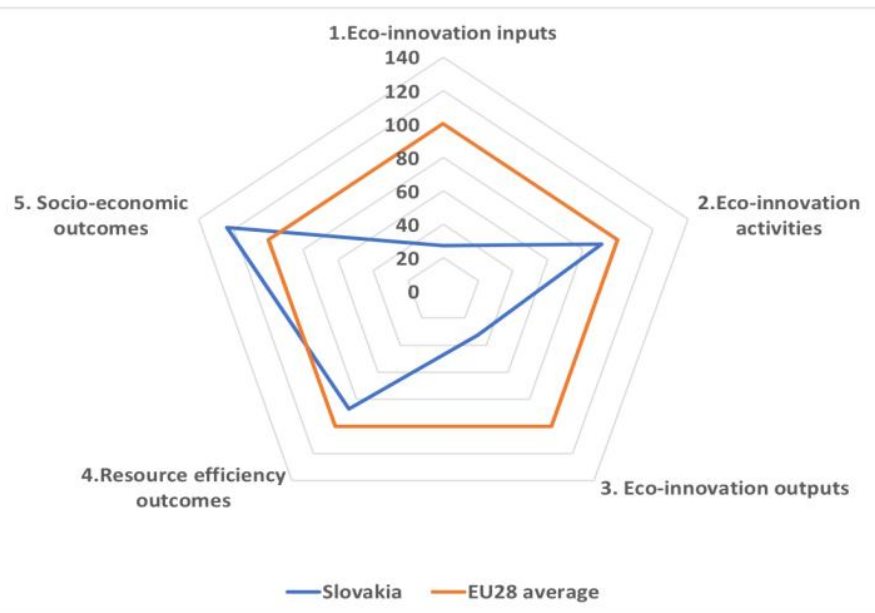

Fig. 2. Components of the Eco-innovation index for Slovakia 2017.

The only component in which Slovakia is above the EU average is socio-economic outcomes, while the four components score below EU average. In order to illustrate the diversity across the EU countries, the minimum and maximum scores as well as the overall score range is illustrated for each of the five components, and also for the aggregated index. (Table 1)

Table 1. Scores in the five components of the Eco-Innovation Index 2017 Slovakia.

\begin{tabular}{|l|c|c|c|c|c|c|}
\hline & $\begin{array}{c}\text { Eco-innov. } \\
\text { Inputs }\end{array}$ & $\begin{array}{c}\text { Eco-innov. } \\
\text { activities }\end{array}$ & $\begin{array}{c}\text { Eco-innov. } \\
\text { outputs }\end{array}$ & $\begin{array}{c}\text { Resource } \\
\text { efficiency } \\
\text { outcomes }\end{array}$ & $\begin{array}{c}\text { Socio- } \\
\text { economic } \\
\text { outcomes }\end{array}$ & $\begin{array}{c}\text { Eco-innov. } \\
\text { index }\end{array}$ \\
\hline Slovakia & 27 & 90 & 33 & 87 & 124 & 74 \\
\hline Minimum-EU & 4 & 10 & 13 & 2 & 6 & 38 \\
\hline Maximum-EU & 200 & 155 & 220 & 183 & 145 & 144 \\
\hline Range-EU & 197 & 145 & 207 & 181 & 139 & 106 \\
\hline
\end{tabular}


As the weakest component of the Eco-innovation index appear the Eco-innovation inputs. Eco-innovation inputs show to what extent the government gives the priority to investments in support of environmental and energy R\&D. It also gives information about $\mathrm{R} \& \mathrm{D}$ human resources in this area. This component is composed of three sub-indices: government environmental and energy R\&D appropriations and outlays (as share of GDP), total environmental and energy $R \& D$ personnel and researchers (as a share of total employment) and total value of green early-stage investments.

The eco-innovation input component had a score of 27 in 2017 (compared to a score of 38 in 2015). Government environmental and energy R\&D appropriations and outlays, as a share of GDP were $0.01 \%$ in 2017 (compared to $0.04 \%$, the EU average). The performance was slightly better for the share of R\&D personnel and researchers out of total employment, with $0.72 \%$ in 2014 compared to an EU average of $1.32 \%$ [17]. The value for green earlystage investments is very low.

Eco-innovation activities include indicators to monitor the scope and scale of ecoinnovation activities undertaken by companies. This component shows to what extent companies in Slovakia are involved in material and energy efficiency eco-innovation, as well as in observing environmental management. The indicators include: firms declaring to have implemented innovation activities aiming at a reduction of material input per unit output ( $\%$ of total firms); firms declaring to have implemented innovation activities aiming at a reduction of energy input per unit output (\% of total firms) and ISO 14001 registered organisations (per mil. population).

Overall component index is 90, which is the second highest (after socio-economic index) among the rest of the indexes. Enterprises that introduced an innovation with environmental benefits obtained within the enterprise and those obtained environmental benefits by the end user are almost the same 0.23 and 0.22 (it is twice lower as EU average 0.53 and 0.50 ). The third indicator of this component is the number of ISO 14001registered organisations per million inhabitants. Slovakia is doing well in this indicator. There were 427 ISO 14001 registered companies per million inhabitants in 2016, which gives an index score of 0.76 , which is well above of EU average 0.30 [17].

Eco-innovation outputs are used to monitor the extent to which knowledge outputs generated by businesses and researchers relate to eco-innovation. Eco-innovation outputs quantify the outputs of eco-innovation activities in terms of patents, publications and media coverage.

Eco-innovation outputs reached an index score of 33. Slovakia's low score in ecoinnovation outputs is explained by the relatively low performance in all three dimensions of EI outputs (eco-patents, EI publications and EI media coverage). The number of ecopatents obtained in 2014 was 2.09 eco-patents per million people. In comparison to the EU average, number of EI patents obtained per million populations amounted to 15.34 in the same year [17].

Resource-efficiency outcomes relate to wider effects of eco-innovation on improved resource productivity. This component measures material, water and energy productivity and greenhouse gas (GHG) emissions intensity.

The overall component score for Slovakia was 87 in 2017, a slight improvement since 2015, when it was 78. Material productivity amounts to $1.76 \mathrm{EUR} / \mathrm{kg}$ in 2015 , which is below the EU average of $2.25 \mathrm{EUR} / \mathrm{kg}$, while energy productivity is $7.85 \mathrm{Eur} /$ toe (the EU average of 9.66 EUE/toe) in 2015 [17]. The GHG emissions intensity is slightly higher in comparison to EU average, amounting to $0.34 \mathrm{CO} 2$ emissions generated per unit of GDP.

Socio-economic outcomes of eco-innovation represent effects of eco-innovation activities for society and the economy. This includes changes in employment turnover or export that relate to broadly understood eco-innovation activities. The indicators for this component include: export of products from eco-industries ( $\%$ of total exports); 
employment in eco-industries and circular economy (\% of total employment); revenue in eco-industries and circular economy ( $\%$ of total revenue).

The overall component score for socio-economic outcomes for Slovakia in 2017 is 127. This is a considerable improvement since 2015, when Slovakia scored only 87 for this component. Employment in eco and circular economy industries was at $2.93 \%$ of total employment in Slovakia in 2016 that is slightly above the EU average of 2.69\%. Ecoindustries' revenue has achieved $4.73 \%$ of total revenue across sectors, which is higher in comparison to the EU- average $2.30 \%$. The share of products from eco-industry in total export was $0.40 \%$ in 2016, which is below the EU average of $0.60 \%$ [17].

It can be stated that thought the eco-innovation overall score has increased during the last years, Slovakia still faces many challenges from wide range of environmental and economic problems.

Eco-innovation inputs and outputs are the weakest components in overall ecoinnovation index. This is mainly due to low public funding in environmental and energy R\&D. Government budget appropriations and outlays for R\&D (usual public funding in Slovakia) lag far behind the EU's average (they are twice lower than the EU average). The public funding is supplemented by the EU funds (mainly the European Structural Funds and Horizont 2020). There is also evident a lack of human resources in research and development. Highly educated persons in the field of engineering and science present a very low share in the national workforce of population, partly due to a tendency of a "braindrain" in Slovakia [18]. Better conditions, international exposure, and a creation of a more competitive environment could improve this situation. As the indicators show, the green early-stage investments are in Slovakia very low.

As the result of low financial support into the environmental and energy R\&D as well as low percentage of workforce in research and development, the eco-innovation outputs related to eco-innovation (eco-patents, EI publications and EI media coverage) is very low ( $14 \%$ of EU average in eco-patents).

What concerns the resource-efficiency outcomes, there are many challenges for Slovakia. The big challenge is to increase the energy and material productivity as well as the green gas (GHG) emissions intensity. Slovakia is committed to the goals of the EU 2030 Agenda and to the 2020 climate and energy package. Share of renewable energy is coming closer to $14 \%$ target for the year 2020 and is mostly covered by Slovakia's traditional clean energy sector based on large hydropower plants and supplemented by a small hydro power biomass and solar. Air protection represents one of the main challenges (the largest sources of such pollution are the transport sector and the residential heating). In October 2017, an amendment to the Air Act was approved. This deals with specific measures to combat the air pollution.

At the same time there are also some strengths; Slovakia outperforms many EU countries in a number of companies with ISO 14001 certification demonstrating aspiration to higher environmental standards in business sector (index Slovakia : EU average $=2.53$ ). This contributed positive to the average score in the Eco-innovation activities.

A positive contribution to the country's overall score was made also by the socioeconomic outcomes, which demonstrated a relatively high share of employment in ecoinnovation and a circular economy industry in the country. Employment in eco and circular economy industries was $9 \%$ more in 2016 than the EU average and what concerns the ecoindustry's revenue it was twice more than EU average.

Thought Slovakia has implemented many of EU policies and measures in the area of environmental policy and eco-innovations to the SR legal system, the progress is slow [19]. Insufficient approximation of the EU directives to the SR legal system in relation to environmental protection and eco-innovation has been criticized by the European Commission. Environmental policy stringency in Slovakia has been assessed as above 
average compared to OECD countries. According to the World Bank, we lag behind other countries in the quality or regulations and law enforcement.

The need for a new, modern environmental strategy which reflects the actual situation and urgent problems of the whole system of environment has resulted at the new "Envirostrategy 2030 for Slovakia" (Strategic Environmental Policy of Slovakia up to 2030, which was approved in February 2019 [20]. The strategy identifies basic system problems, sets 2030 targets, proposes framework measures to improve the current situation and contains also basic performance indicators for verification of achieved results. The strategy underlines the role of eco-innovations.

\section{Conclusion}

It can be stated that eco-innovations in Slovakia face many challenges. Based on the above analysis, the main implications for policy makers and managers in Slovakia may be formulated:

- Policy makers in Slovakia should place greater emphasis on sufficient approximation of EU directions to the legal system of the SR. They have to create effective policy programs and measures supporting eco-innovation and helping to establish a stable platform for eco-innovation's development.

- Public funding and expenditure in the eco-research and development is still low in Slovakia. To tackle with this issue both state as well as public and private institutions have to be more involved in the financial support.

- It is necessary to raise firm's awareness about eco-innovations and green business as business with a high added value in relation to the corporate responsibility concept as well as to raise firm's awareness about the necessity to implement stabile and continual environmental business strategy.

- In cooperation with central government authorities and professional organizations, academia and non-governmental organizations, the more efficient system of formal and informal environmental education and training for sustainable development has to be implemented.

Eco-innovations call attention to the positive contribution that the companies can make to sustainable development and a competitive economy [21]. Hence, eco-innovation is understood as the combined improvement of economic and environmental performance of society.

\section{References}

1. J. Horbach, Determinants of Environmental Innovation - New Evidence from German Panel Data Sources. Research Policy 37, 163-173 (2008)

2. S. Terjesen, P.C. Patel, In search of Process Innovations: The Role of Search Depth, Search Breadth, and the Industry Environment. Journal of Management 43, 1421-1446 (2017)

3. P. Del Rio Gonzales, The empirical analysis of the determinants for environmental technological change: a research agenda. Ecological Economics 68, 861-878 (2009)

4. A. Cozzolino, G. Verona, F. Rothaermel, Unpacking the Disruption Process: New Technology, Business Models, and Incumbent Adaptation. Journal of Management Studies 55, 1166-1202 (2018)

5. M. A. León-Ledesma, M. Satchi, Appropriate Technology and Balanced Growth. The Review of Economic Studies 86, 807-835 (2019) 
6. L. Kogan, et al., Technological Innovation, Resource Allocation, and Growth. The Quarterly Journal of Economics 132, 665-712 (2017)

7. C. Fussler, P. James, Driving eco-innovation: a breakthrough discipline for innovation and sustainability (Pitman Ltd., London, 1996)

8. B. Hillebrand, P. Driessen, Adoption and diffusion of green innovations. In Nielsen, W. \& Bartels, G., Marketing for sustainability: towards transactional policy making (IOS Press Inc., Amsterdam, 2002)

9. A. Arundel, R. Kemp, Measuring eco-innovation. UNU-MERIT 2009-017, Amsterdam. [Online]. Available: http://www.merit.unu.edu/publications/wppdf/2009/ wp2009-017.pdf (2009)

10. K. Rennings, Redefining innovation - eco innovation research and the contribution from ecological economics. Ecological Economics 32, 319-332 (2000)

11. S. Azevedo, et al., Eco-Innovation and the Development of Business Models (Springer International Publishing, Switzerland, 2014)

12. R. Kemp, P. Pearson, Final Report of the MEI project Measuring Eco-Innovation (UM Merit, Maastricht, 2007)

13. Eco-innovation Observatory, Eco-Innovation Action Plan. [Online]. Available at: https://ec.europa.eu/environment/ecoap/about-action-plan/objectives-methodology_ andactions/ (2011)

14. Eco-innovation Observatory, Europe in transition. Paving the way to a green economy through eco-innovation. [Online]. Available at: https://www.eco-innovation.eu/ index.php/reports/eco-innovation-briefs (2013)

15. Eco-Innovation Observatory, EU Eco-Innovation Index 2017. EIO Brief. [Online]. Available at: https://ec.europa.eu/environment/ecoap/scoreboard_en/ (2018)

16. L. Lesáková, The critical view on Innovation Activity in SME's Sector in Slovakia. (137-149). In Dias, A., Salmelin, B. (Eds.), Modeling Innovation Sustainabity and Technologies. Economic and Policy Perspectives. Springer International Publishing Switzerland (2018)

17. Eco-innovation Observatory, Eco-innovation Country Profile 2016-2017. [Online]. Available at: https://ec.europa.eu/environment/ecoap/country/profiles/ (2018)

18. SBA - Slovak Business Agency, Analýza využivania eko-inovácií a obehovej ekonomiky $v$ prostredi MSP. [Online]. Available at: http://www.sbagency.sk/ sites/default/files/7_anal_vyuzivania_eko-inovacii-a-prvkov-obehovej-ekonomiky/ pdf/ (2018)

19. L. Lesáková, Ekologické inovácie $v$ činnosti malých a stredných podnikov. (Ekonomická fakulta Univerzity Mateja Bela, Banská Bystrica, 2019)

20. MŽP - Ministerstvo životného prostredia SR. Envirostratégia 2030. [Online]. Available at: https://www.minzp.sk/iep/strategicke-materialy/envirostrategia-2030/ (2019)

21. A. B. Jaffe, R. Newell, R. Stavins, A tale of two market failures: technology and environmental policy. Ecological Economics 54, 164-174 (2005) 